\title{
USE OF PETITIONS BY MINORITY GROUPS TO DENY BROADCAST LICENSE RENEWALS
}

\section{INTRODUCTION}

Under the Communications Act of $1934,{ }^{1}$ the Federal Communications Commission (FCC) is empowered to issue broadcast licenses for three-year terms to a particular applicant only "if the public convenience, interest, or necessity will be served thereby." 2 At the end of each three-year license term, the FCC must make an affirmative finding that the public interest would be served by renewal of the broadcaster's license. ${ }^{3}$ The broadcast licensee has no property interest in its license; ${ }^{4}$ it becomes in effect a trustee for the public, and in accepting the franchise it assumes enforceable public duties. $^{5}$

Despite the need for the FCC to make a determination during license renewal proceedings as to the public interest, until 1966 members of the general listening public did not have standing to challenge license renewals. ${ }^{6}$ As late as 1965, in Lamar Life Broadcasting Co. ${ }^{7}$ the FCC stated:

The Commission has consistently held that members of the general public who do not show a direct causal relationship between the action being protested and some injury of a tangible and substantial nature have no standing purely as members of the general public. . . . Here petitioners, as members of a minority group can assert no greater interest or claim of injury than members of the general public. Otherwise, any minority group based on race, creed, color, or national origins could gain standing as a representative of the public interest despite the lack of an individual substantive right to protect or a substantial and immediate interest in the matter protested. ${ }^{8}$

1. 47 U.S.C. $\S 307$ (d) (1970).

2. Id. $\S 307(\mathrm{a})$.

3. Id. $\S 307(\mathrm{~d})$.

4. "[N]o such license shall be construed to create any right, beyond the terms, conditions, and periods of the license." Id. § 301. See FCC v. Sanders Bros., 309 U.S. 470, 475 (1940); Citizens Communications Center v. FCC, 447 F.2d 1201, 1209 n.23 (D.C. Cir. 1971); Note, Petitioning to Deny Broadcast License Renewals, 16 WASHBURN L.J. 375, 375-76 (1977).

5. Office of Communication of the United Church of Christ v. FCC, 359 F.2d 994, 1003 (D.C. Cir. 1966).

6. See Note, supra note 4, at 376-77 for a more detailed history of standing of third parties in broadcast license renewal proceedings. Prior to 1966 a petitioner had to allege a specific injury or interest which was unique and distinct from that of the listening public at large, such as electrical interference or economic injury. $I d$.

7. 38 F.C.C. 1143 (1965).

8. Id. at $1149 \mathrm{n} .11$ (emphasis in original). 
However, the following year in Office of Communication of the United Church of Christ v. FCC ${ }^{9}$ the District of Columbia Court of Appeals interpreted section 309(d) of the Communications Act, ${ }^{10}$ holding that an organization with substantial membership in a licensee's service area or an individual similarly situated may acquire standing to challenge a license renewal by alleging fairness doctrine violations or racial or religious discrimination. ${ }^{11}$ As a result, the petition to deny broadcast license renewals provided by section 309(d) became available as a potentially powerful tool to compel licensees to become more responsive to the needs of the listening public.

It would appear that "petitions to deny" would be particularly valuable to minority groups. A minority group comprising a significant percentage of the population of a broadcasting area ${ }^{12}$ might assert that if a broadcast licensee's programming is to serve the public convenience, interest and necessity, it must be relevant to that group's problems and lifestyles. Therefore, if the view of reality presented by a given broadcast licensee is largely from a white, male, middle class or upperclass perspective, ${ }^{13}$ that licensee may not be serving the public interest. However, minority groups have been markedly unsuccessful in obtaining licensee responsiveness through the use of section 309 (d). This has been due partially to the considerable substantive burdens and procedural requirements facing any petitioner to deny. ${ }^{14}$ But in addition, the petition for a minority group faces some peculiar problems. This Note will discuss briefly the procedural and substantive requirements for a petition to deny and then examine the grounds for petitions to deny that have been of particular interest to minority groups. Finally, it will examine several recent changes in this area which indicate that increased receptivity to petitions to deny by minority groups may be forthcoming.

\section{Standing AND PRocedural ReQuirements ${ }^{15}$}

The pre-eminent procedural requirement for a petition to deny is that it

9. 359 F.2d 994 (D.C. Cir. 1966). See Note, supra note 4, at 376 for a detailed discussion of this case after remand.

10. 47 U.S.C. \& 309(d) (1970).

11. 359 F.2d at $998-1006$.

12. See Black Broadcasting Coalition v. FCC, 556 F.2d 59 (D.C. Cir. 1977); Avco Broadcasting Corp., 53 F.C.C. $2 \mathrm{~d} 48$ (1975).

13. Since most licensees derive their income from commercial advertisers, their natural tendency is to structure their programming to appeal to those groups with the greatest spending power. See N.O.W., N.Y. City Chapter v. FCC, 555 F.2d 1002, 1013 nn.69-73 (D.C. Cir. 1977); American Broadcasting Co., 52 F.C.C.2d 98, 113 (1975) (discussing the slanted view of women's place in society presented by certain soap operas and entertainment programs).

14. See Note, supra note 4 , at 377 . On the particular problems of minority groups, see Note, F.C.C. Failure to Eradicate Employment Discrimination, 21 ST. Louls U.L.J. 150 (1977); Note, The F.C.C.'s Role in Providing Equal Employment Opportunity for Minority Groups, 53 D.U.L. REV. 657 (1973).

15. The procedural and standing requirements for a petition to deny have been treated in detail in Note, supra note 4, at 378-80. Because the difficulties encountered by minority groups 
be timely. ${ }^{16}$ Although the FCC does have the discretion to consider the issues raised in a petition to deny that is filed after the deadline by treating the petition as an informal objection, ${ }^{17}$ it is not obligated to do so.

Assuming it is filed on time, the petition must contain specific allegations of fact sufficient to show standing and to show that a grant of the application would not be in the public interest. ${ }^{18}$ If the petitioner is an individual who resides within the licensee's service area or an organization with members who reside within the service area, standing is satisfied. However, the petition will be denied and the license granted without a hearing ${ }^{19}$ if the petition does not allege specific facts sufficient to show that a grant of the application would be prima facie inconsistent with the public interest, convenience and necessity and create a substantial and material question of fact as to whether the renewal would be in the public interest. ${ }^{20}$ The grounds for the petition must be stated with exacting specificity; mere conclusions and general allegations are not sufficient. ${ }^{21}$ An affidavit "of a person or persons with personal knowledge" of the alleged fact must support every allegation. ${ }^{22}$

If the petitioner fulfills the procedural and standing requirements and raises substantial and material questions of fact, a hearing is mandatory. ${ }^{23}$ If a hearing is designated, ${ }^{24}$ the petitioner will have the burden of going

utilizing petitions to deny can be discussed only in light of these procedural requirements, it is necessary to treat them briefly here.

16. Petitions to deny generally must be filed by the first day of the last full calendar month of the expiring term. 47 C.F.R. \$§ 1.516(e), 1.580(i) (1976).

17. WOIC, Inc., 39 F.C.C.2d 355, 355 n.1 (1973); Applications of Certain Colo. Commercial and Non-Commercial Broadcast Stations for Renewal of License, 28 F.C.C.2d 375, 377 (1971); Newhouse Broadcasting Corp., 8 F.C.C.2d 1123 (1967); Hubbard Broadcasting Co., 8 F.C.C.2d 647, 648 (1967); see 47 C.F.R. $\$ 1.587$ (1976).

18. 47 U.S.C. \& 309(d)(1) (1970).

If the Commission finds on the basis of the application, the pleadings filed, or other matters which it may officially notice that there are no substantial and material questions of fact and that a grant of the application would be consistent with subsection (a) of this section, it shall make the grant, [and] deny the petition . . . .

Id. $\S 309(\mathrm{~d})(2)$.

19. Id. $\$ 309(\mathrm{~d})(2)$.

20. See Hartford Comm. v. FCC, 467 F.2d 408, 410 (D.C. Cir. 1972).

21. Midland Broadcasters, Inc., 48 F.C.C.2d 195, 196 (1974).

22. 47 U.S.C. $\S 309$ (d)(1) (1970).

23. Id. $\S 309$ (d)(2), (e).

24. It seems possible that a hearing might in some situations be mandatory under section 309(e) even though the petition to deny does not satisfy the section 309(d) tests. Theoretically, a petition could raise enough doubts as to the licensee's qualifications to prevent the FCC from affirmatively finding that renewal would be in the public interest without presenting substantial and material facts sufficient to show that renewal would be prima facie inconsistent with the public interest.

To necessitate a hearing the petition would still have to allege material facts, that is, facts which are "material to the determination of the question whether the public interest, convenience, or necessity would be served by granting the application." Stone v. FCC, 466 F.2d 316, 
forward with the introduction of the evidence, and the Commission may determine the allocation of burdens of proof with respect to any particular issue presented. ${ }^{25}$ The Commission need not notify the petitioner that its petition requires further substantiation nor enable the petitioner to correct the deficiency. ${ }^{26}$ Because of this, the petition must be drafted with great care.

\section{GROUNDS For PETITIONS to DENY}

\section{A. Challenges to Programming. ${ }^{27}$}

The direct approach for minority groups seeking responsive programming would be to allege that the licensee's programming is biased and ignores the interests and problems of the minority community. Such challenges may be based on the FCC's fairness doctrine or on the licensee's unresponsiveness to community needs, although neither type of challenge is often successful.

1. Fairness Doctrine. The fairness doctrine requires balanced programming when the licensee deals with controversial issues of public concern. ${ }^{28}$ The licensee has wide discretion in choosing the manner in which it fulfills its fairness doctrine obligations. ${ }^{29}$ The licensee must make rea-

323 (D.C. Cir. 1972) (quoting H.R. REP. No. 1800, 86th Cong., 2d Sess. 12 (1960)). 47 U.S.C. $\$$ 309(d)(2) (1970) provides that "if a substantial or material fact is presented or if the Commission for any reason is unable to find that grant of the application would be consistent with subsection (a) of this section [public interest standard], it shall proceed as provided under subsection (e) of this section" (emphasis added). Subsection (e) provides for designating a hearing if the Commission is unable to make the finding required in subsection (a). However, the District of Columbia Circuit has suggested that unless section $309(\mathrm{~d})(1)$ is satisfied, a hearing is not required. Broadcast Enterprises, Inc. v. FCC, 390 F.2d 483 (D.C. Cir. 1968).

25. 47 U.S.C. $\& 309$ (e) (1970). 47 C.F.R. $\$ 1.254$ (1976) provides that the burden of proof upon all issues specified by the Commission shall be on the applicant except as otherwise provided in the order of designation.

26. Daily Tel. Printing Co., 59 F.C.C.2d 185, 195 (1976).

27. This. Note is concerned only with broadcast licensees' responsiveness to minority groups; thus it will only treat grounds for petitions to deny that relate to programming and employment discrimination. For a full treatment of possible grounds for petitions to deny by groups representing the general viewing or listening public, see Note, supra note 4, at 380 .

28. A petition to deny based on fairness doctrine violations must contain the following information: (1) the specific public issue of a controversial nature presented by the station; (2) the date and time of the broadcast; (3) the basis for the claim that the issue was a controversial issue of public importance; (4) the basis for the claim that the station broadcasted only one side of the issue; and (5) whether the station has afforded or has expressed an intention to afford a reasonable opportunity for the presentation of contrasting views. Newhouse Broadcasting Corp., 61 F.C.C.2d 528, 541 (1976).

29. "[T]he licensee is given initial and primary responsibility in making the decision as to the adequacy with which it has presented contrasting views on the issue in question. This wide discretion must be respected, in the absence of unreasonableness or bad faith. . . " Id. at 541 . 
sonable judgments as to whether a controversial issue of public importance is involved, what viewpoints have been or should be presented and the format and spokesmen to be used in presenting those viewpoints. ${ }^{30}$ The licensee is not required to devote the same amount of time to both sides, nor to grant time to any particular person or group under the fairness doctrine. ${ }^{31}$ Isolated violations do not require a hearing since the Commission examines the licensee's programming for overall balance. ${ }^{32}$

The Commission will not interfere with this discretion without evidence of bad faith. ${ }^{33}$ The Commission has held that the first amendment and section 326 of the Communications Act, ${ }^{34}$ which prohibits censorship, preclude it from dictating to the licensee which controversial issues to air and in what format. ${ }^{35}$ Because of these discretionary aspects of the doctrine and the often narrow definition of the phrase "discussion of a controversial issue," 36 only the most blatant violations will result in a hearing. ${ }^{37}$ The

30. Brandywine-Main Line Radio, Inc. v. FCC, 473 F.2d 16, 44 (D.C. Cir. 1972).

31. Id.

32. Lamar Life Broadcasting Co., 38 F.C.C. 1143, 1145 (1965). Occasional "ethnic slurs" have been held not to constitute fairness doctrine violations. Avco Broadcasting Corp., 53 F.C.C.2d 48 (1975).

33. See Committee to Elect Jess Unruh Our Next Governor, 25 F.C.C.2d 726 (1970): "[T]he decision as to what constitutes a controversial issue of public importance is made by the licensee based on his reasonable, good faith judgment, and is subject to Commission review only as to the reasonableness and good faith of the licensee's judgment." See also Applicability of the Fairness Doctrine in the Handling of Controversial Issues of Public Importance, 40 F.C.C.2d 598, 599 (1964)

34. 47 U.S.C. $\$ 326$ (1970).

35. CBS, Inc., 56 F.C.C.2d 296, 298 (1975).

36. See N.O.W., N.Y. City Chapter v. FCC, 555 F.2d 1002, 1014 (D.C. Cir. 1977). In that case, N.O.W. alleged that the licensee had violated the fairness doctrine by broadcasting soap operas, entertainment programs and commercial announcements that presented a slanted and stereotyped view of women. N.O.W. contended that the programming portrayed women as "incompetent, dependent, over-emotional and irresponsible." Id. at 1013.

The Commission held that the subtle built-in bias that affected the licensee's programming did not amount to an "advocacy of a position" on the issue of women's role in society, and therefore did not constitute a "discussion" of this controversial issue for purposes of the fairness doctrine. National Broadcasting Co., 52 F.C.C.2d 273, 286 (1975).

On appeal, the District of Columbia Circuit did not decide the issue of whether the licensee's portrayal of women amounted to a "discussion" of women's role in society, holding that even if the programming did amount to such a discussion the licensee had afforded a reasonable opportunity to be heard. N.O.W., 555 F.2d at 1014-15. In light of N.O.W., there is serious doubt as to whether the fairness doctrine could ever be used to combat instances of subtle, pervasive bias in programming content.

37. Office of Communication of the United Church of Christ v. FCC, 425 F.2d 543 (D.C. Cir. 1969), provides an example of how blatant a violation of the fairness doctrine must be before an abuse of licensees' discretion will be found. The licensees, WLBT and WJDT, had given only the segregationist view concerning the Little Rock desegregation crisis and had deliberately cut off an NBC program in which Justice Thurgood Marshall, then general counsel of the NAACP, was appearing. The Commission renewed the license in 1959 despite fairness doctrine objections holding that "isolated failures to comply with the fairness doctrine do not result in denial of renewal." Lamar Life Broadcasting Co., 38 F.C.C. 1143, 1145 (1965). 
fairness doctrine has been of little help to minority groups seeking responsive programming. ${ }^{38}$

2. Responsiveness to Community Needs. A licensee's renewal may be challenged on the ground that its past programming has been unresponsive to community needs. Although the licensee has a duty "to meet the particular needs, interests and local community problems of his service area," 39 the manner in which it fulfills this duty is largely within its discretion..$^{40}$ The licensee may decide which problems merit treatment, how much time to devote to each problem and when to present the programming geared to these problems. ${ }^{41}$

The FCC does not measure the licensee's responsiveness in terms of its programming concerning a particular minority group. ${ }^{42}$ Programming will not be determined unresponsive because the percentage of minority participants is low, ${ }^{43}$ because some particular entertainment program may offend minority viewers ${ }^{44}$ or because the amount of programming dealing with a particular minority group is less than the percentage of that group's representation in the community. ${ }^{45}$ Further, allegations that the renewal appli-

In 1965 when WLBT's and WJDT's licenses were again up for renewal the FCC determined that the fairness doctrine had been violated because the licensees' one-sided pro. gramming on racial issues had continued and was reflected in its coverage of James Meredith's enrollment at the University of Mississippi. Id. at 1146, 1154. The Commission still did not designate a hearing; instead it conditionally renewed the license for one year. Id. at 1154 . When the case was appealed for the second time, after being remanded on an intervention issue, the District of Columbia Circuit held that the Commission erred in renewing the license despite the fairness doctrine violations, and that the renewal was not supported by the evidence. $425 \mathrm{~F} .2 \mathrm{~d}$ at 550 .

See also Brandywine-Main Line Radio, Inc. v. FCC, 473 F.2d 16 (D.C. Cir. 1972) (fairness doctrine violation found where station was being used by a right-wing preacher to expound his own religious views and disparage other religions).

38. The corollaries to the fairness doctrine-the personal attack rule, the equal time rule and the political editorializing rule-will not be discussed here. The latter two pertain only to broadcasts concerning political candidates. The personal attack rule has not been useful to minority groups because it involves only a limited opportunity to reply to broadcasts which attack a minority group. Isolated racial slurs have not been held to violate this rule. See Avco Broadcasting Corp., 53 F.C.C.2d 48 (1975). This rule is remedial, providing only a means of ameliorating damaging broadcasts and is not for the purpose of affirmatively effecting responsive programming. For a discussion distinguishing the personal attack and equal time rules from the fairness doctrine see Note, supra note 4, at 382-84.

39. Time-Life Broadcast, Inc., 33 F.C.C.2d 1050, 1055 (1972).

40. Columbus Broadcasting Coalition v. FCC, 505 F.2d 320, 327 (D.C. Cir. 1974).

41. RadiOhio, Inc., 38 F.C.C.2d 721, 738 (1973), aff'd sub nom. Columbus Broadcasting Coalition v. FCC, 505 F.2d 320 (D.C. Cir. 1974).

42. WCSC, Inc., 61 F.C.C.2d 570,575 (1976).

43. KSD/KSD-TV, 61 F.C.C.2d 504, 514 (1976).

44. CBS, Inc., 59 F.C.C.2d 1127, 1133 (1976); American Broadcasting Co., 52 F.C.C. $2 \mathrm{~d} 98$, 106 (1975); Taft Broadcasting Co., 38 F.C.C.2d 770, 793 (1973); RadiOhio, Inc., 38 F.C.C.2d 721, 742 (1973), aff'd sub nom. Columbus Broadcasting Coalition v. FCC, 505 F.2d 320 (D.C. Cir. 1974).

45. CBS, Inc., 56 F.C.C.2d 296, 301 (1975). The District of Columbia Circuit has agreed 
cant's news coverage of a minority group is biased or distorted are insufficient to show unresponsiveness unless there is evidence of deliberate exclusion of news items ${ }^{46}$ or "extrinsic evidence that the licensee has falsified, distorted or suppressed news." 47

In order to make out a prima facie case on the responsiveness issue, the petition must contain specific allegations of fact which if proved would establish that the licensee's overall past or proposed programming did not, or will not, reasonably meet the interests of the persons within the station's service area, including black and other minority groups.$^{48}$ Such a burden has been in most cases insurmountable. ${ }^{49}$

\section{B. Ascertainment of Community Needs.}

Each licensee must ascertain the "problems, needs and interests of the people of his community." 50 Because a challenge to ascertainment is grounded on the procedure employed by the licensee, first amendment issues are not involved. Ascertainment involves four steps: ${ }^{51}$ (1) a compositional study to determine the various groups that comprise the community; 52 (2) consultation with representatives or leaders of these groups to identify community problems and needs; (3) a random survey of the general public

with this approach to the responsiveness issue, emphasizing the licensee's discretion in this area. Stone v. FCC, 466 F.2d 316, 328 (D.C. Cir. 1972):

How a broadcast licensee responds to what may be conflicting and competing needs of regional or minority groups remains largely within its discretion. It may not flatly ignore a strongly expressed need; on the other hand, there is no requirement that a station devote twenty percent of its broadcast time to meet the need expressed by twenty percent of its viewing public... [the] scope of FCC review remains whether or not the licensee has reasonably exercised its discretion.

46. CBS, Inc., 56 F.C.C.2d 296, 300 (1975).

47. WOIC, Inc., 39 F.C.C.2d 355, 367 (1973). The "extrinsic evidence" needed has been defined as "testimony, oral or written" from those who have "direct personal knowledge of an intentional attempt to distort, stage or slant the news." Outlet Co., 38 F.C.C. $2 \mathrm{~d} 355,363$ (1972).

48. CBS, Inc., 46 F.C.C.2d 903, 910-11 (1974). The petition should be supported by affidavits which show that the licensee failed to meet a substantial number of problems in programming or that it refused in bad faith to meet a significant community problem. Id.

49. In the following cases, challenges to programming responsiveness failed because the licensee was not shown to have abused its discretion: Radio Akron, Inc., 62 F.C.C.2d 987, 995 (1977); State Telecasting Co., 62 F.C.C.2d 309, 315 (1977); Sonderling Broadcasting Corp., 62 F.C.C.2d 303, 306 (1977); Westinghouse Broadcasting Co., 48 F.C.C.2d 1123, 1130 (1974); KSAY Broadcasting Co., 47 F.C.C.2d 584, 593 (1974); CBS, Inc., 46 F.C.C.2d 903 (1974); WGN of Colo., Inc., 35 F.C.C.2d 789 (1972); Evening News Ass'n, 35 F.C.C.2d 366, $391-92$ (1972).

50. Primer on Ascertainment of Community Problems by Broadcast Applicants, 27 F.C.C.2d 650,657 (1971).

51. See id. at 682-87.

52. See N.O.W., N.Y. City Chapter v. FCC, 555 F.2d 1002, 1005-07 (D.C. Cir. 1977). The ascertainment in N.O.W. was claimed to be defective because the licensee did not list women as one of the significant groups within the community, and because even though the licensee interviewed female community leaders, it did not interview them in their capacity as representatives of the women's movement. Id. 
to identify community problems and needs; and (4) preparation of responsive programs and announcements.

Recently the FCC has provided licensees with a checklist of community groups whose leaders should be surveyed in ascertaining community interests and needs. ${ }^{53}$ If the licensee interviews leaders from each category on the checklist, its leadership survey cannot be challenged on the grounds that a significant group was omitted or because fewer leaders of a particular minority were surveyed than that minority's representation in the community might warrant. ${ }^{54}$ All that is required is that the licensee conduct a survey of a cross-section of community leaders. ${ }^{55}$ If the licensee follows the checklist, it will almost certainly be regarded as having complied with this requirement.

The problems faced in challenging the licensee's survey of the general public are similar to those encountered in challenging the leadership survey. Low representation of minorities in the sample does not necessarily produce a defective ascertainment. As long as the sample is truly random and there is no evidence of deliberate exclusion of any group the general survey is immune from attack. ${ }^{56}$

The policy of permitting "upgrading" has also made challenges to a licensee's ascertainment of community interest difficult. Unlike programming challenges, which force the licensee to "run on his record," 57 ascertainment is seen by the FCC to be prospective in nature. Licensees have been allowed to upgrade a defective ascertainment by amending their original applications even after a petition to deny has been filed. ${ }^{58}$ Although

53. Ascertainment of Community Problems by Broadcast Applicants, 57 F.C.C.2d 418, 418-19, 425-26 (1976).

54. Time-Life Broadcast, Inc., 33 F.C.C.2d 1081, 1097 (1972).

55. RadiOhio, Inc., 38 F.C.C.2d 721, 724 (1973), aff'd sub nom. Columbus Broadcasting Coalition v. FCC, 505 F.2d 320 (D.C. Cir. 1974). The near impossibility of challenging a leadership survey is demonstrated by Daily Tel. Printing Co., 59 F.C.C.2d 185 (1976). Of 103 community leaders interviewed by the licensee, eighty-seven were businessmen, governmental leaders or lawyers. Despite the underrepresentation of blacks, welfare recipients and low income people generally, the leadership survey was held adequate because these groups were not totally excluded. Id. at 185-86.

56. Great Trials Broadcasting Corp., 39 F.C.C.2d 39, 42 (1972); Outlet Co., 38 F.C.C.2d 355,358 (1972).

57. Columbus Broadcasting Coalition v. FCC, 505 F.2d 320, 326 (D.C. Cir. 1974).

58. Stone v. FCC, 466 F.2d 316, 324-25 (D.C. Cir. 1972). In Stone, it was argued that permitting last minute ascertainment would prevent petitioners from effectively policing the ascertainment rules. The court suggested that by prodding the licensee into substantial compliance through the filing of an amendment the petition had the same policing effect even if the petition was subsequently denied. Id. However, on a motion for rehearing the court seemed to back away from this position, suggesting that in the future if any individual licensee persisted in waiting for a petition to deny to remedy its ascertainment efforts this would amount to bad faith and would not be countenanced. Id. at 332. The defective ascertainment would then be a sufficient issue to warrant designating a hearing. See notes 145-49 infra and accompanying text. 
amendments will not be accepted if they are in "bad faith," this limitation has only been applied in extreme circumstances. ${ }^{59}$ Due to the use of the community leader checklist and upgrading, challenges to renewal based on faulty ascertainment have not been practical. ${ }^{60}$

\section{Employment Discrimination.}

The FCC's Equal Employment Opportunity (EEO) rules ${ }^{61}$ place two responsibilities upon the licensee: the negative duty of refraining from discrimination and the positive duty of formulating and implementing a satisfactory affirmative action plan. ${ }^{62}$ These two responsibilities are by no

59. See Bamford v. FCC, 535 F.2d 78 (D.C. Cir. 1976), and Rust Communications Group, Inc., 53 F.C.C.2d 355 (1975), where there were repeated attempts to amend in the face of obvious ascertainment violations. For recent developments in the "bad faith" exception, see notes 145-54 infra and accompanying text.

60. Not only have challenges to ascertainment surveys not been a practical basis for petitions to deny, but there is some question as to whether proper ascertainment has much utility for minority groups except when seeking to redress specific problems. The D.C. circuit court has commented on some of the broader possibilities of ascertainment:

Many of the plaintiff's objections centered around the station's failure to deal with the black culture with sensitivity and sympathy. The FCC's ascertainment procedures speak largely in terms of ascertaining and dealing with community "problems." Community life, however, does not consist entirely of problems . . . . It might be desirable for ascertainment proceedings to inquire into more than the problems or newsworthy events in a community. Such proceedings might be directed toward obtaining an awareness of the broad range of human activity that includes family life, art, and social interaction ... The FCC, however, in its rulemaking capacity is clearly the proper forum for posing objections to the quality and nature of the media programming.

Stone v. FCC; 466 F.2d 316, 328 n.44 (D.C. Cir. 1972).

61. In 1969, the FCC adopted nondiscrimination rules which prohibit broadcast licensees from discriminating in employment on the basis of "race, color, religion or national origin" and require licensees to undertake equal employment opportunity programs. Petition for Rulemaking tó Require Broadcast Licensees to Show Nondiscrimination in their Employment Practices, 13 F.C.C.2d 766 (1968). The following year form " 395 " was adopted for the annual reporting of employment statistics, and discrimination on the basis of sex was prohibited. See Petition for Rulemaking to Require Broadcast Licensees to Show Nondiscrimination in their Employment Practices, 23 F.C.C.2d 430 (1970). In 1972 licensees were required to include women in their equal employment opportunity program filed with the Commission. Equal Opportunity Program, 32 F.C.C.2d 831 (1971).

New rules requiring licensees with over fifty fulltime employees to submit more detailed EEO plans were adopted recently. Non-discrimination in the Employment Policies and Practices of Broadcast Licensees, 60 F.C.C.2d 226 (1976). Stations with less than five employees were initially exempt from the requirement of filing an affirmative action plan and form " 395. " 23 F.C.C.2d 430 (1970). In 1976 this exemption was expanded to include licensees that employed ten or more full time individuals. 60 F.C.C.2d 266 (1976). However, the Second Circuit recently voided the FCC's modification of the exemption. Office of Communication of the United Church of Christ v. FCC, 560 F.2d 529 (2d Cir. 1977).

62. Newhouse Broadcasting Corp., 61 F.C.C.2d 528, 537 (1976); see 47 C.F.R. \$§ 73.125, $73.301,73.680$ (1975). These three rules, which apply to AM, FM and television respectively, provide:

(a) General policy. Equal opportunity in employment shall be afforded by all licensees ... to all qualified persons, and no person shall be discriminated against in employment because of race, color, religion, national origin or sex. 
means distinct. In the past, the Commission had indicated that it will not scrutinize a licensee's affirmative action plan unless a violation of the negative duty is first established. ${ }^{63}$ Moreover, the existence of an affirmative action plan in satisfaction of the positive duty has often been held to be determinative of whether the negative duty was violated. ${ }^{64}$

1. The Negative Duty - "Zone of Reasonableness" and Active Discrimination. Many FCC and circuit court decisions require evidence of active discrimination before a hearing concerning possible violations of the FCC's EEO rules will be designated. The petitioner must allege specific instances of discrimination ${ }^{65}$ or a pattern of facts that point to a policy of conscious discrimination, ${ }^{66}$ or he must demonstrate that the licensee's employment practices contain barriers to equal employment opportunity ${ }^{67}$

A statistical disparity between the percentage of minority workers on the licensee's staff and their representation in the area work force will not automatically raise an employment discrimination issue. ${ }^{68}$ Isolated instances of discrimination are also insufficient to force a hearing. ${ }^{69}$ The petition must be neither too specific nor too general; it must allege specific instances of discrimination but allege enough of them to demonstrate a general policy or pattern of discrimination.

Although a pattern of employment discrimination with an accompanying statistical disparity in the licensee's employment record appears to be the only allegation that is reasonably certain to compel the Commission to hold a hearing, a petition alleging less may be successful. A disparity that is so substantial as to be outside the "zone of reasonableness" 70 will raise a

(b) Equal employment opportunity program. Each station shall establish, maintain and carry out, a positive continuing program of specific practices designed to assure equal opportunity in every aspect of station employment policy and practice . . . .

Id.

63. Time-Life Broadcast, Inc., 33 F.C.C.2d 1050 (1972).

64. Bilingual Bicultural Coalition of Mass Media, Inc. v. FCC, 492 F.2d 656, 658 (D.C. Cir. 1974) (Bilingual I); Southern Broadcasting Co., 62 F.C.C.2d 146, 148 (1977) ("a low minority or female employment profile at a station is subject to rebuttal by an equal opportunity program designed to correct the underutilization"). See also New York Times Broadcasting Serv., Inc., 63 F.C.C.2d 695, 699 (1977); Radio Akron, Inc., 62 F.C.C.2d 987, 992 (1977); National Broadcasting Co., 61 F.C.C.2d 523, 525 (1976).

65. Stone v. FCC, 466 F.2d 316, 329 (D.C. Cir. 1972); Outlet Co., 38 F.C.C. $2 d$ 355, 363

(1972); WTAR Radio-TV Corp., 31 F.C.C.2d 812, 833 (1970).

66. Columbus Broadcasting Coalition v. FCC, 505 F.2d 320, 328 (D.C. Cir. 1974); Outlet Co., 38 F.C.C.2d 355, 366 (1972).

67. Columbus Broadcasting Coalition v. FCC, 505 F.2d 320 (D.C. Cir. 1974); 1972 License Renewal Applications for 17 Broadcast Facilities Licensed to the Richmond, Va. Area, 54 F.C.C.2d 953 (1975).

68. Time-Life Broadcast, Inc., 33 F.C.C.2d 1050, 1058 (1972).

69. Community Media Corp., 61 F.C.C.2d 493 (1976).

70. Stone v. FCC, 466 F.2d 316, 332 (D.C. Cir. 1972) (seven percent black employment by licensee in a metropolitan area with twenty-four percent black population held to be within zone of reasonableness). 
question as to whether a "pattern" or "policy" of discrimination exists or whether there is a barrier to minority employment. ${ }^{71}$ But unless the disparity is quite substantial ${ }^{72}$ the FCC will impose lesser sanctions rather than holding a hearing. ${ }^{73}$

The "zone" determination is generally based on the aggregate percentage of all minorities hired, not on the percentage representation of any one minority group. ${ }^{74}$ Further, the Commission will not compare the percentage of minorities in upper job categories with the percentage of minorities in the local area when deciding whether the licensee is within the zone. ${ }^{75}$ To raise an issue of underutilization of minority employees or discrimination in promotion the petitioner must allege that all minority employees of the licensee are in low-paying or menial positions. ${ }^{76}$

The Commission considers its function under its EEO rules to be prospective in nature. When a license is considered for renewal the FCC attempts to determine whether the licensee's future employment practices will satisfy the public interest standard set forth in its generic statute. ${ }^{77}$ The Commission will, therefore, look at the licensee's employment statistics

71. A "highly disproportionate representation of minorities employed by a licensee in relation to their presence in the work force could constitute prima facie evidence of discriminatory practice." Rust Communications Group, Inc., 53 F.C.C.2d 355, 362 (1975).

72. In the few cases in which the Commission has ordered a hearing on employment practices, the licensees had engaged in virtually no minority hiring. Federal Broadcasting Sys., Inc., 59 F.C.C.2d 356 (1976); Rust Communications Group, Inc., 53 F.C.C.2d 355 (1975).

73. Non-discrimination in the Employment Policies and Practices of Broadcast Licensees, 60 F.C.C.2d 226, 229 (1976).

74. There have been a few instances where the FCC did make a separate zone determination as to one minority group. In Mission Central Co., 54 F.C.C.2d 581, 586 n.3 (1975), the Commission noted: "Where a single protected group predominates to the extent the Mexican Americans do in the San Antonio area, [44 percent] we feel it appropriate to direct the licensee to assure that the affirmative action taken under its EEO program reaches and involves the dominant group." See KRMD, Inc., 53 F.C.C.2d 1179, 1187 (1975).

75. "[W]here no actual discrimination in filling responsible positions has been established, the placement of employees, including minority group employees, in particular positions is and must remain a part of the licensee's discretion in the operation of its broadcast station." New York Times Broadcasting Serv., Inc., 63 F.C.C.2d 695, 699 (1977); see Westinghouse Broadcasting Co., 48 F.C.C.2d 1123, 1135 n.15 (1974); Miami Valley Broadcasting Corp., 48 F.C.C.2d 177, 180 (1974); Evening News Ass'n, 35 F.C.C.2d 366, 395 (1972).

76. Stone v. FCC, 466 F.2d 316, 330 (D.C. Cir. 1972). Nondiscrimination in the Employment Policies and Practices of Broadcast Licensees, 60 F.C.C.2d 226, 228 (1976); Columbia Broadcasting Sys., Inc., 46 F.C.C.2d 903, 916-17 (1974); Outlet Co., 38 F.C.C.2d 355, 366 (1972); Evening News Ass'n, 35 F.C.C.2d 366 (1972).

The difficulty of challenging license renewals on the basis of low minority employment in managerial positions is a severe hindrance to minorities seeking to affect programming through the enforcement of the FCC's EEO rules. Programming and format decisions are usually made in the upper levels of management. It is only in such positions of responsibility that minority representation will result in programming which is more responsive to minority needs.

77. N.O.W., N.Y. City Chapter v. FCC, 555 F.2d 1002, 1016-17 (D.C. Cir. 1977); see 47 U.S.C. \& 307(a) (1970). 
after the period of alleged discriminatory practices and at its affirmative action efforts, in addition to its prior record, in determining whether a hearing is required. A disparity that is initially unreasonable may become reasonable in the light of an active affirmative action plan. ${ }^{78}$

A finding by the Equal Employment Opportunity Commission (EEOC) of reasonable cause to believe there has been discrimination does not in itself raise a sufficient issue to warrant a hearing as to the licensee's fulfillment of its negative duty under the FCC's EEO rules. ${ }^{79}$ The FCC views the substantive requirements of its own rules to be of a different nature from those imposed on all employers by Title VII, ${ }^{80}$ and it views its enforcement role as different from that of the EEOC. ${ }^{81}$ Although an EEOC finding of reasonable cause may not automatically mandate an FCC hearing, the FCC declines to act on allegations of employment discrimination while an EEOC proceeding is pending ${ }^{82}$ or ongoing. ${ }^{83}$ In such cases renewal of a license may be granted without a hearing if no issues other than employment discrimination are raised, but approval would be conditioned on the out-

78. Bilingual Bicultural Coalition of Mass Media, Inc. v. FCC, 492 F.2d 656, 658 (D.C. Cir. 1974).

79. National Broadcasting Co., 58 F.C.C.2d 419, 422 (1976).

80. 42 U.S.C. $\$ \$ 2000 \mathrm{e}-2000 \mathrm{e}-15$ (1970). The F.C.C. has held:

[I]t appears that the showings of prima facie inconsistency with the public interest under Section 309(d) of the Communications Act and of reasonable cause to believe the truth of discrimination charges under Title VII . . . are of a different nature and weight. That is, a finding of "reasonable cause" by the EEOC does not raise, $a$ fortiori, a substantial question requiring a hearing under Section 309(d).

National Broadcasting Co., 58 F.C.C.2d 419, 421 (1976).

81. The Commission views the EEOC's function as oriented toward individuals, attempting if at all possible through conciliation to make aggrieved persons whole. The EEOC's finding of reasonable cause, according to the FCC, may not lead to an evidentiary hearing, but to "informal methods of conference, conciliation, and persuasion." Id. (citing section 706(a) of the Civil Rights Act of 1964, 42 U.S.C. $\$ 2000$ e-5(a) (1970)).

The FCC's function, however, under its EEO rules must be connected with its overall purpose of promoting broadcasting that satisfies the public interest, convenience and necessity:

Our responsibility, therefore, is not the regulation of employment discrimination per

se... [W] need not make a finding that instances of discrimination in violation of

Title VII have or have not occurred. Even assuming the occurrence of these past violations, our task is to assess their significance in light of the applicant's subsequent performance and present compliance with our EEO rules. Thus, the Commission's regulatory emphasis is to assure that the broad public interest is served. ... [W] conclude that the determination of the effect of an adverse EEOC finding of "reasonable cause to believe'" upon the qualifications of a broadcast licensee rests ultimately with the Commission.

National Broadcasting Co., 58 F.C.C.2d 419, 422 (1976). See also King's Garden, Inc. v. FCC, 498 F.2d 51 (D.C. Cir. 1974) (FCC may deny license renewal because of religious discrimination in hiring practices of sectarian radio station even though 1972 amendment to Title VII explicitly exempts religious organizations).

82. The Commission defers to the EEOC while that agency's proceedings are pending, presumably because it does not wish to interfere with or duplicate the EEOC's investigation. N.O.W., N.Y. City Chapter v. FCC, 555 F.2d 1002, 1016-17 (D.C. Cir. 1977).

83. Even in cases where the EEOC has issued a finding of reasonable cause, the FCC declines to act on the discrimination issue so long as the parties are still in the "conciliation" stages of the EEOC proceeding. Id. 
come of the EEOC proceeding. ${ }^{84}$ This deference, which has been criticized, ${ }^{85}$ is incongnuous with the FCC's policy that it alone must determine the weight of an EEOC reasonable cause finding in light of its own standards. ${ }^{86}$

2. Affirmative EEO Duty. The FCC's EEO rules require licensees actively to recruit, employ and promote qualified members of minority groups, and to formulate an EEO plan reasonably calculated to draw qualified minority candidates. ${ }^{87}$ The FCC will first look to the licensee's "paper plan" 88 and then determine the effectiveness in practice of the affirmative action plan by again examining the licensee's employment statistics. ${ }^{89}$ In

84. Horizon Communications Corp., 61 F.C.C.2d 498, 500 (1976).

85. The Commission's renewal of a license without a hearing in a case where there was an EEOC finding of reasonable cause drew a persuasive dissent in Meredith Corp., 65 F.C.C.2d 174 (1977). Because the licensee's employment statistics were within the "zone of reasonableness," the FCC renewed the license of KMBC-TV of Kansas City, Mo., without further inquiry into or evaluation of the licensee's EEO performance. In the petition to deny the NAACP had alleged discrimination against blacks in the licensee's hiring, training and promotion practices. Commissioner Fogarty dissented, stating:

Although the licensee, Metromedia, has had annual employment profiles within the

SMSA statistical "zone of reasonableness," complainant nonetheless alleges that blacks are discriminated against. . . [T] [Te E.E.O.C. determination tends to support this allegation in that it finds "reasonable cause" to credit a former black employee's charge that her race was a factor in her rate of pay and termination.

Id. at 181. Commissioner Fogarty would not have granted renewal without further scrutiny of the licensee's employment practices.

86. Horizon Communications Corp., 63 F.C.C.2d 233, 233-34 (1977). The FCC's practice of renewing licenses without a hearing despite an EEOC finding of reasonable cause is difficult to reconcile with the FCC's obligation to renew a license only if it is able affirmatively to find that such renewal would be in the public interest.

47 U.S.C. $\$ 309$ (e) (1970) requires a hearing whenever a "substantial and material question of fact is presented or the Commission for any reason is unable to make the finding" that renewal would be in the public interest. An EEOC finding of reasonable cause should arguably be enough to preclude the FCC from making the public interest finding necessary under this section unless there is a full evidentiary hearing to satisfy the Commission that the employment practices which led to the EEOC proceeding have been discontinued. If no hearing is designated when there is an EEOC reasonable cause finding, the Commission should at least make its own informal review of the licensee's employment practices before granting a renewal, regardless of whether the licensee's statistics are within the "zone of reasonableness."

87. Newhouse Broadcasting Corp., 61 F.C.C.2d 528, 537 (1976).

88. The EEO plans usually include such efforts as advertising in magazines or newspapers with minority group readership, recruiting from universities with a large female or minority enrollment, maintaining contacts with women's and minority organizations to obtain referrals of possible candidates and use of equal opportunity employment agencies. Training programs are also common but are not required. WCSC, Inc., 61 F.C.C.2d 570, 572 (1976).

89. The procedural steps in the Commission's examination of a licensee's EEO program are as follows: (a) review of any required EEO program for completeness under the rules; (b) examination of the station's actual minority and/or female employment profiles, as appropriate, in an effort to determine the acceptability of the employment results in view of the licensee's efforts to implement the EEO program; (c) further inquiry, usually by letter, when questions are raised by the program or when its results are not satisfactorily explained by the information on hand; (d) field investigation when substantial questions remain even after written exchange of information; (e) grant of renewal conditioned upon periodic reporting of EEO information, 
determining whether the EEO plan is effective the FCC may consider statistics for periods subsequent to the license term. ${ }^{90}$ The number of minorities in the upper job categories during the license and post-license periods is also relevant to the determination of whether the affirmative action plan is effective. ${ }^{91}$ Thus, if the licensee's affirmative action plan is "active" or "effective," the licensee could be within the "zone of reasonableness" even if its performance during the license term would not have elevated it to that level, ${ }^{92}$ while a lack of post-license improvement may place the initial statistical disparity outside the zone of reasonableness. ${ }^{93}$ However, a hearing may not result in such a case even if the disparity is outside the zone. Except where intentional discrimination is demonstrated, ${ }^{94}$ the FCC prefers the lesser sanctions of short-term renewal with the adoption of an adequate affirmative action plan ${ }^{95}$ or of conditional renewal with detailed reporting requirements. ${ }^{96}$

\section{RECENT CHANGES-N.O.W., BLACK COALITION AND BILINGUAL II}

Petitioners seeking to deny a license renewal encounter extremely difficult burdens of proof regardless of the grounds upon which they choose to base their petitions. The demanding standards required to challenge a license renewal application because of fairness doctrine violations or lack of responsiveness to community needs are not likely to be changed as the first amendment may preclude infringement of licensee discretion in these areas.

when the licensee is qualified but further EEO monitoring appears appropriate in the public interest; and (f) designation of the renewal application for hearing if there are unresolved substantial and material questions of fact concerning discrimination or aggravated noncompliance with EEO rules. Non-discrimination in the Employment Policies and Practices of Broadcast Licensees, 60 F.C.C.2d 226, 241-42 (1976).

90. Columbus Broadcasting Coalition v. FCC, 505 F.2d 320 (D.C. Cir. 1974); see notes 111 13 infra and accompanying text.

91. National Broadcasting Co., 58 F.C.C.2d 419, 422 (1976); CBS, Inc., 51 F.C.C.2d 273, 274-76 (1975); 1972 License Renewal Applications for 17 Broadcast Facilities Licensed to the Richmond, Va. Area, 54 F.C.C.2d 953, 958 (1975).

The EEO program may be deemed effective even if the post-license improvement is slight. In C.B.S., Inc., 51 F.C.C.2d 273, 274-75 (1975), the minority employment at stations KCBS and KCBS-FM rose from 10.9 to 16.7 percent, and from 13.4 to 18.3 percent, respectively, in an area with a 28 percent minority population. The Commission held "that the station's employment of minorities falls within a zone of reasonableness, and that it has undertaken affirmative action to improve the employment status of minorities. This [was] evidenced by the upward trend in the numbers of minorities employed and in their positions." Id. at 276.

92. CBS, Inc., 51 F.C.C.2d $273,274-76$ (1975).

93. WCSC, Inc., 61 F.C.C.2d 570, 573-74 (1976).

94. Non-discrimination in the Employment Policies and Practices of Broadcast Licensees, 60 F.C.C. $2 d$ 226, 228 n.4 (1976).

95. Mission Central Co., 54 F.C.C.2d 581 (1975); Triple X Broadcasting Co., 51 F.C.C.2d 585 (1975); Bob Jones Univ., Inc., 42 F.C.C.2d 522 (1973).

96. Meredith Corp., 65 F.C.C.2d 174, 180 (1977). See also WCSC, Inc., 61 F.C.C.2d 570, 573 (1976) (FTC imposed detailed reporting requirements but renewal was not granted at that time due to other matters pending). 
Although challenges to ascertainment or discriminatory practices are not subject to first amendment constraints, the Commission's prospective approach has also made these challenges difficult. Faulty ascertainments may be amended or the licensee may hide behind the shield of marginally improved employment statistics, leaving substantial disparities unexplained if the Commission is satisfied that the licensee's post-license statistics and EEO efforts indicate that it will comply with the Commission's EEO rules in the future. ${ }^{97}$ Recent cases, however, indicate that improved post-licenseterm data ${ }^{98}$ and amended ascertainments ${ }^{99}$ will no longer avoid the consequences of past violations, and that the licensee may be compelled to submit to prehearing discovery. ${ }^{100}$

\section{A. Limitations on the Prospective Approach to Employment Discrimina- tion.}

The FCC has repeatedly held that its evaluation of a licensee's performance under its nondiscrimination rules is not to be based solely on statistics, but on a combination of the licensee's employment statistics and its overall efforts at minority recruitment and employment. Often this has meant that evidence of discrimination during a license term would be ignored if postlicense improvement seemed to demonstrate that the licensee's infractions would not be carried over into later license terms.

In Stone v. $F C C^{101}$ the District of Columbia Circuit affirmed a decision of the $\mathrm{FCC}^{102}$ to renew the license of Washington, D.C., television station WMAL after taking into account that station's post-license employment statistics. Petitioners in the case had charged WMAL with discrimination

97. See KSD/KSD-TV, Inc., 61 F.C.C.2d 504, 514-15 (1976). KSD applied for license renewal in 1973. KSD's annual employment report for 1973 showed 7.01 percent minority employment in a metropolitan area where minorities comprised 14.5 percent of the total work force (St. Louis itself had a minority population of 50 percent). Id. at 513 . KSD's '1973 figures showed 14.03 percent female employment in a metropolitan area where women made up 36.77 percent of the total work force. Id. at 514-15. Although the 1973 statistics were poor, the license was renewed, id. at 516, because by $1976 \mathrm{KSD}$ 's minority and female employment had risen to 14.0 percent and 24.0 percent respectively. Id. at $513-14$. The renewal was conditioned upon the final outcome of three complaints with the EEOC.

See also the District of Columbia Circuit's disapproval of the Commission's use of postlicense improvement to shield poor license-term performance in Black Broadcasting Coalition v. FCC, 556 F.2d 59, 64 n.21 (D.C. Cir. 1977).

98. Black Broadcasting Coalition v. FCC, 556 F.2d 59, 61-62 (D.C. Cir. 1977); see notes 133-43 infra and accompanying text.

99. 556 F.2d at 61 n.2; see notes $145-54$ infra and accompanying text.

100. Bilingual Bicultural Coalition on Mass Media, Inc. v. FCC, No. 75-1855 (D.C. Cir. Apr. 20, 1977), 13 Empl. Prac. Dec. (CCH) II 11,622 (Bilingual II, vacated on rehearing en banc, No. 75-1855) (D.C. Cir. May 4, 1978); see notes $155-200$ infra and accompanying text.

101. 466 F.2d 316 (D.C. Cir. 1972).

102. Evening Star Broadcasting Co., 27 F.C.C.2d 316 (1971). 
against blacks, contending that only three percent of the licensee's noncustodial personnel were black as compared with a seventy percent black population in the city. ${ }^{103} \mathrm{WMAL}$ challenged those statistics, stating that as of May 27, 1969 (five months before the three-year license was to terminate) its minority employment had increased to eight percent ${ }^{104}$ and since that time had risen to over eleven percent. ${ }^{105}$ The court found that these statistics, ${ }^{106}$ along with an affidavit of the licensee explaining its efforts to recruit minority members and to place them in a variety of positions, were sufficient to rebut the allegations of discrimination. ${ }^{107}$ In so doing, the court emphasized that the sole question to be determined in deciding if a hearing is warranted is whether the "aggregate picture" presented by the licensee's employment practices makes out a prima facie case for refusing license renewal. ${ }^{108}$

On a petition for rehearing the court clarified its decision by stating that it had not held that "statistical evidence of an extremely low rate of minority employment will never constitute a prima facie showing of discrimination, or 'pattern of substantial failure to accord equal employment opportunities.' "109 The court left the door open for challenges based on employment statistics alone if the licensee's employment statistics were outside a "zone of reasonableness." 110

The court restated this position in Columbus Broadcasting Coalition v. $F C C,{ }^{11}$ where post-license data formed the basis for a determination that a hearing on allegations of discrimination was not required prior to renewal of a license. In that case, the court noted that the number of blacks employed by the licensee had risen during the two years after its license term had ended, ${ }^{112}$ and it used this information in determining that the licensee's

103. 466 F.2d at 330 n.51; see Evening Star Broadcasting Co., 27 F.C.C. $2 d$ 316, 327 (1971).

104. $466 \mathrm{~F} .2 \mathrm{~d}$ at $330 \mathrm{n} .51$. The court's figures are slightly different from those provided in the FCC's opinion, see 27 F.C.C.2d at 327.

105. 466 F.2d at 330 n. 51 .

106. In addition to citing the improved employment statistics, the court determined on rehearing that the pertinent population with which to compare the figures was the Washington metropolitan area, rather than the city itself. In the metropolitan area, the black population was only 24 percent. Id. at 332 .

107. Id. at 330 .

108. Id. at 329 .

109. Id. at 332 .

110. Id.

111. 505 F.2d 320 (D.C. Cir. 1974).

112. The petitioner in the case, Columbus Broadcasting Coalition, alleged that there was a disparity between the number of blacks employed by Columbus, Ohio, television station WBNS-TV, and the percentage of blacks in the Columbus metropolitan area. It was determined that at the time the pleadings in the case were filed the station employed 15 blacks in noncustodial positions, representing 8.3 percent of its work force, as compared with an 11.6 percent black population in the Columbus metropolitan area. Id. at 329. But the court also noted that in the two years following the end of the station's license term its black employment had risen to 9.5 percent and 10 percent, respectively. Id. 
minority hiring fell within the zone of reasonableness. ${ }^{113}$ The license was renewed despite a complaint of discrimination by one employee, ${ }^{114}$ indicating that allegations of isolated acts of discrimination are not sufficient to warrant a hearing.

A refinement of these holdings in Bilingual Bicultural Coalition of Mass Media, Inc. v. FCC (Bilingual $)^{115}$ further supports the view that post-license data are relevant to the "zone" determination. The court noted the holding in Stone that a statistical disparity alone does not establish a prima facie case for denying license renewal when the licensee has a policy of recruiting minority group members and placing them in responsible jobs. ${ }^{116}$ But the court also noted that on a petition for rehearing the Stone court indicated that statistics outside the zone of reasonableness could constitute such a prima facie showing. ${ }^{117}$ The court concluded that " $\left.t\right]$ he two opinions in Stone should, of course, be read together-a disparity that is reasonable in light of recruitment policy might not be reasonable in its absence." 118 Thus, Bilingual I necessarily sanctioned the practice of considering postlicense data as part of the "zone" determination; if the "zone" determination is to include evaluation of the EEO plan, this can only be done by examining post-license-term statistics, which are the most reliable indicator of the EEO plan's effectiveness.

The District of Columbia Circuit in N.O.W., N.Y. City Chapter v. $F C C^{119}$ appeared to give its express approval to the FCC's use of postlicense data in determining licensee compliance with its equal employment standards, but it indicated there may be some limitations on this practice. The court affirmed the FCC's decisions ${ }^{120}$ granting renewal of the licenses

113. Id. at 329. The court affirmed the decision of the Commission to refuse the petitioner's request for a hearing. The Commission had concluded that because "minority persons represented 10 percent of the licensee's total full-time workforce in [the two years following the expiration of the license in question] . . . the composition of the WBNS stations' minority staff falls within a range of reasonableness." RadiOhio, Inc., 38 F.C.C.2d 721, 746 (1973).

The Commission held that no hearing was warranted on the discrimination issue since the petitioners did not allege that the licensee's employment policies and practices created barriers to equal employment opportunity or that the licensee consciously discriminated, resulting in a "pattern of discrimination." Id.

114. 505 F.2d at 329.

115. 492 F.2d 656 (D.C. Cir. 1974).

116. Id. at 658 ; see Stone, $466 \mathrm{~F} .2 \mathrm{~d}$ at $329-30$.

117. 492 F.2d at 658 ; see Stone, 466 F.2d at 332 .

118. 492 F.2d at 658 .

119. 555 F.2d 1002, 1016 (D.C. Cir. 1977).

120. National Broadcasting Co., 52 F.C.C.2d 273 (1975); American Broadcasting Co., 52 F.C.C.2d 98 (1975). In National Broadcasting Co., N.O.W. asserted that only 22.3 percent of the employees of a Washington, D.C., television station were women, whereas 48 percent of the Washington, D.C., work force was female. 52 F.C.C.2d at 288. The Commission first considered WRC's license-term statistics, which revealed that in 1971 the station's staff was 24 percent female and that in 1972 only 22.5 percent was female. Id. at 294 . The FCC concluded 
of WABC-TV in New York and WRC-TV in Washington, D.C. N.O.W. had challenged WABC's renewal by arguing that "the 'poor statistical comparison' between the percentage of women on the [licensee's] staff and the percentage of women in the area's workforce constituted a prima facie showing of sex discrimination," 121 basing its allegations on the licensee's employment statistics during the station's 1969-1972 license term. ${ }^{122}$ N.O.W.'s allegations concerning WRC were similar, again relying on the license-term statistics. ${ }^{123}$ After initially finding that the stations' license-

that "[w]hile WRC's female employment is within a current zone of reasonableness, we are concerned by the fact that, as of the 1972 Annual Employment Report, $88 \%$ of the station's male staff were in the upper four job categories, but only $24.4 \%$ of the female staff were similarly situated." Id. Because of the discrepancy between men and women in the upper four job categories, the FCC stated that the "applicant's affirmative action plan" was of "particular significance." Id.

The Commission's decision to examine the licensee's affirmative action plan after finding that its statistics were within the zone of reasonableness is puzzling. Immediately prior to deciding that an examination of the EEO plan was needed, the FCC stated: "In cases where employment profile falls outside a . . . 'zone of reasonableness,' the licensee must modify or supplement its recruitment practices and policies by vigorous and systematic efforts to locate and encourage the candidacy of qualified minorities." Id. at 293. The Commission stated that the consequences of the licensee's employment practices, not its intent, determined whether remedial action was necessary. Id. at 294. Either the Commission had only made a tentative "zone" finding on the aggregate statistics but was following Bilingual $\Gamma$ 's admonition to assess the disparities in light of the station's recruitment policies, see notes 115-18 supra and accompanying text, or the Commission had decided that the affirmative action obligation was totally independent and there was no need to find that the licensee's employment statistics were outside the zone of reasonableness before examining its EEO plan.

In evaluating WRC's EEO plan, the FCC determined that the plan was an operating success, as revealed by the post-license-term statistics in the licensee's Annual Employment Reports for 1973 and 1974. In 1973 WRC's-female employment had increased to 28 percent and in 1974 women made up 40 percent of the licensee's staff. Id. at 294-95.

In American Broadcasting Co. after the Commission found that the licensee's performance was within the zone of reasonableness, 52 F.C.C.2d at 121, it examined the efficacy of the licensee's EEO plan using post-license-term data. Id. at 122.

121. 555 F.2d at 1015 .

122. Id. at 1015 n.89. Information supplied by WABC showed 23.3 percent of its work force was female, but that 72 percent of those women were in clerical positions. Women comprised 40.3 percent of the area work force. Id.

123. Id. at 1016. In 1972, WRC's full-time staff was 22.5 percent women in an area where women represented 48 percent of the work force. Id. at 1016 n.92.

There was an additional allegation against WRC concerning an EEOC finding of "reasonable cause." Id. at 1016. N.O.W.'s petition to deny WRC's license alleged that the EEOC had issued a finding of "reasonable cause to believe" that virtually all managerial job categories had always been male, that all but one of the managers at that time were male, and that there were a large number of all-male categories. 52 F.C.C. $2 \mathrm{~d}$ at 288 . The Commission had deferred to the EEOC for a determination of these issues. 52 F.C.C.2d at 293. See notes 79-86 supra and accompanying text.

After the EEOC proceedings came to an impasse and coriciliation was no longer possible, the FCC obtained a temporary remand. 555 F.2d at 1016. In a supplemental opinion the FCC found that N.O.W.'s charges did not necessitate a hearing. National Broadcasting Co., 58 F.C.C.2d 419, 421-22 (1976). 
term statistics were within the zone of reasonableness, the FCC in both cases considered post-license-term statistics to support this initial finding. ${ }^{124}$

On appeal, the District of Columbia Circuit held that the post-licenseterm data were relevant and were properly considered by the Commission. The court recognized that the Commission's "public interest" power to regulate employment discrimination derives its scope from the Communications Act. ${ }^{125}$ Consequently the employment practices of licensees are relevant to the Commission's determinations to the extent that those practices affect the obligation of the licensees to provide programming that "fairly reflects the tastes and viewpoints of minority groups." 126 In furthering this statutory mandate the FCC may "focus "prospectively" " on the problem of employment discrimination with "primary concentration on EEO plans that seek to erase the causes of past discrimination." 127 However, in doing so the FCC need not punish past discrimination, but may confine itself to the issue of whether the licensee is presently in compliance with the Commission's rules. ${ }^{128}$ In assessing an EEO plan's effectiveness, the Commission must examine employment data over a "significant period of time,", which can include the post-license-term period. ${ }^{129}$

Although the court did not explicitly place limitations on the use of post-license-term data in N.O.W., the decision did contain some warning signals of possible boundaries. Post-license data were not used to make the initial "zone" determination, ${ }^{130}$ but only to evaluate the effectiveness of the affirmative action plan. The court made special note of the fact that the licensees' employment figures were initially within the zone of reasonableness and that the post-license data were used only to reinforce this finding. ${ }^{131}$ This suggested that post-license-term improvement might not be used to counteract a negative "zone" determination.

If $N . O . W$. approved the use of post-license-term data only for determining the effectiveness of a licensee's EEO plan and not for making the initial zone determination, the case represents a significant development in defining the scope of a licensee's affirmative EEO duty and its negative obligation to refrain from discrimination. Bilingual $I$ had intermingled these two obligations. ${ }^{132}$ Under the Bilingual $I$ test, any post-license data that

124. 52 F.C.C.2d at $294-95 ; 52$ F.C.C. $2 d$ at $122-23$.

125. $555 \mathrm{~F} .2 \mathrm{~d}$ at 1017.

126. Id. at 1017 (citing NAACP v. FPC, 425 U.S. 662,670 n.7 (1976)).

127. 555 F.2d at 1019.

128. Id. at 1020 .

129. Id. at 1019.

130. Id. at 1015-16.

131. "Initially the Commission looked at the bare percentages of women employed and determined that the figures were within the 'zone of reasonableness'. . . ." Id. at 1018.

132. See notes 115-18 supra and accompanying text. 
constituted evidence of the station's compliance with its affirmative action duty would be relevant to the "zone" determination for purposes of deciding whether its employment statistics warranted the inference of active discrimination. If $N . O . W$. severed the two determinations, it would no longer be possible for a licensee whose license-term statistics were not within the zone of reasonableness to avoid a hearing by implementing a vigorous affirmative action program.

The limitation on the use of post-license-term data that had been implied in N.O.W. was made explicit in a recent opinion of the District of Columbia Circuit on the subject, Black Broadcasting Coalition $v$. FCC. ${ }^{133}$ There the court reversed the FCC's renewal of the licenses of Stations WTVR-AM-FM and WTVR-TV, ${ }^{134}$ Richmond, Virginia because the Commission had based the renewal on the licensee's post-license-term improvement even though its-license-term statistics were outside the zone of reasonableness. ${ }^{135}$ In holding that a hearing was required, the court stated that post-license-term statistics could not be used to justify renewal without a hearing when two criteria were met: " $[w]$ here overt discrimination is responsibly claimed and licensee's minority employment during the license

133. 556 F.2d 59 (D.C. Cir. 1977).

134. Roy H. Park Broadcasting of Va., Inc., 54 F.C.C.2d 995 (1975); 1972 License Renewal Applications for 17 Broadcast Facilities Licensed to the Richmond, Va. Area, 54 F.C.C.2d 953 (1975).

In these cases, the Black Broadcasting Coalition filed two petitions alleging employment discrimination involving stations WTVR-AM-FM and WTVR-TV owned by Roy H. Park Broadcasting Co. of Virginia, Inc. The first complaint was a market-wide challenge to the license renewal of seventeen stations in the Richmond area, including WTVR-AM-FM and WTVR-TV. 1972 License Renewal Applications for 17 Broadcast Facilities Licensed to the Richmond, Va. Area, 54 F.C.C.2d 953 (1975). The petitioners based their challenge on the stations' 1972 employment data and on individual instances of discrimination. Id at 954. Petitioners also alleged a lack of "job upgrading" for black employees and contended that blacks were not being hired in sufficient numbers in responsible positions. Id. at 954-55.

In the individual petition to deny against WTVR-AM-FM and WTVR-TV, the allegations regarding employment discrimination were much the same. The Black Broadcasting Coalition relied on the station's employment statistics during the license period. There were also two complaints by individuals concerning discriminatory hiring and firing. Roy H. Park Broadcasting of Va., Inc., 54 F.C.C.2d 995, 999 (1975).

135. $556 \mathrm{~F} .2 \mathrm{~d}$ at 61 . Although WTVR-AM-FM and WTVR-TV had 1.5 percent and 0 percent black employment respectively in 1972 during the license period, figures that the FCC considered to be outside the zone of reasonableness, the Commission also considered 1975 postlicense-term data. By that year, WTVR-AM-FM and WTVR-TV had 9.5 percent and 13.7 percent black employment respectively in an area with a 24.2 percent black work force. Roy $\mathrm{H}$. Park Broadcasting of Va., Inc., 54 F.C.C.2d 995, 999 (1975). The Commission found the 1975 figures within the zone of reasonableness, thus justifying renewal. Id. at 1000. But because the small improvement in WTVR-AM-FM's statistical profile from 1973 to 1975 was the result of reduction in staff and not an increase in minority employees, the Commission held there was insufficient data upon which to approve without reservation WTVR-AM-FM's renewal application. Therefore, monitoring conditions and detailed reporting requirements were attached to WTVR-AM-FM's renewal. Id. 
term is below the 'zone of reasonableness,' a strong case for a hearing on the licensee's compliance with its obligation not to discriminate is made out." 136 Under this formulation, a poor license-term performance could not be ignored. ${ }^{137}$ Black Broadcasting Coalition made it clear that N.O.W. approved the FCC's use of post-license-term statistics only for determining the efficacy of affirmative action plans and not for making the initial zone determination. ${ }^{138}$

The FCC argued that its use of the licensee's post-license-term data was justified, relying on Bilingual I's holding that "a disparity that is reasonable in light of a recruitment policy might not be reasonable in its absence." 139 According to Bilingual $I$, the affirmative action plan was relevant to the "zone" determination. N.O.W. had allowed the use of postlicense data to determine the efficacy of the affirmative action plan. ${ }^{140}$ Therefore, it seemed to follow that the FCC could make its "zone" determination based on improved post-license statistics that were the result of an effective EEO plan. However, in Black Broadcasting Coalition the court

136. 556 F.2d at 64 .

137. Id. at 61.

Although Black Broadcasting Coalition ostensibly requires a two-part finding to compel a hearing - that the license-term statistics were outside the zone of reasonableness and that there were responsible charges of overt discrimination by the licensee-there are indications in the opinion that the presence of either ingredient might suffice. The court berated the Commission because "[t]he past history of 1.5 percent or less black employment . . . in an area where blacks constitute about one fourth of the local work force went wholly unexplored." Id. at 6162. This suggests that license-term statistics alone, if outside the zone of reasonableness, might make a hearing mandatory, curtailing the FCC's discretionary use of lesser sanctions in such cases. The court also specifically left open the question of whether individual allegations of discrimination would call for a hearing if the licensee's minority employment statistics had at all times been within the zone of reasonableness. Id. at $62 \mathrm{n} .5$.

138. The court distinguished Black Broadcasting Coalition from N.O.W. See notes 119-32 supra and accompanying text. In N.O.W., the court explained, the District of Columbia Circuit affirmed Commission orders that found license-term statistics to be within the zone of reasonableness. In the court's view, the post-license-term data presented in N.O.W. were considered only for the purpose of verifying the efficacy of the licensee's EEO plan in bringing more women into the top four management levels at the licensee's station. Using post-licenseterm data to make the "zone" determination was not acceptable. 556 F.2d at 61 n.3.

139. Roy H. Park Broadcasting of Va., Inc., 54 F.C.C.2d 995, 1000 (1975) (quoting Bilingual $I, 492$ F.2d at 658); see note 118 supra and accompanying text. In its decision on the marketwide challenge the Commission stated that "[w]here the licensee has an incongruence in the proportionate minority representations on his workforce and the minority available work force, it has an obligation to make reasonable good faith efforts to recruit and hire minorities. 1972 License Renewal Applications for 17 Broadcast Facilities Licensed to the Richmond, Va. Area, 54 F.C.C.2d 953, 957 (1975). A licensee who is unable to recruit such individuals in spite of good faith efforts would not be appropriately sanctioned by the Commission." Id. at 958. In determining whether the licensee has made "good faith" efforts to recruit, the FCC commented: "We have looked at the matter in relation to performance not only during the license period, but also during the post-license period." Id.

140. See notes 119-29 supra and accompanying text. 
refused to consider the licensee's EEO plan in making its "zone" determination. Post-license improvement due to an effective EEO plan could not be used to bring a licensee's poor license-term performance into the zone of reasonableness. The licensee's duty to avoid active discrimination and its affirmative action duty were seen to be two separate obligations ${ }^{141}$ which would have to be independently tested. ${ }^{142}$ Thus, Black Broadcasting Coalition seems to create the possibility that a licensee with a statistical disparity that is within the zone of reasonableness might still have to face a hearing on its affirmative action responsibility if it had a "passive" EEO plan:

The Commission has insisted that the affirmative action is a separate obligation of licensees, independent of nondiscrimination. Accordingly, it is quite possible that a station which performs its obligation of nondiscrimination will have some minority or women employees and yet be lacking an affirmative action program of the positive sort envisioned by the Commission. ${ }^{143}$

Black Broadcasting Coalition eliminates the necessity of proving a violation of the negative duty not to discriminate before obtaining scrutiny of the licensee's EEO plan. ${ }^{144}$

\section{B. Upgrading Ascertainments-Expanding the Bad Faith Exception.}

As noted above, ${ }^{145}$ licensees in the past have been free to amend their renewal applications with new data in order to avoid a hearing if their original ascertainment of community needs was faulty. Although the District of Columbia Circuit in Stone v. FCC ${ }^{146}$ held that upgrading the quality of ascertainments in this way is permissible, ${ }^{147}$ it cautioned that "[i]f in the future any individual licensee persists in waiting for a Petition to Deny, . . . to remedy its prospective [ascertainment] efforts, this could amount to bad faith and should not be countenanced." 148 This "bad faith" limitation

141. 556 F.2d at 64 n.21.

142. Id.

143. Id. But cf. Bilingual Bicultural Coalition on Mass Media, Inc. v. FCC, No. 75-1855 (D.C. Cir. May 4, 1978) (suggesting that hearings are necessary only in cases of intentional discrimination and not in cases of passive affirmative action plans but leaving open question whether unzealous prosecution of an affirmative action plan may be evidence of intentional discrimination).

144. "[T]he Commission and the courts would be remiss to allow unexplored doubts about a licensee's affirmative action program to be shielded by a hopeful, but erratic and equivocal, statistical record." 556 F.2d at 64 n.21.

The Commission recently confirmed the independence of the affirmative action program in Leflore Broadcasting Co., 65 F.C.C.2d 556 (1977), holding that the licensees' failure to implement an adequate EEO plan violated the Commission's rules, finding it unnecessary to determine if there had been active discrimination. Id. at 564 n.20.

145. See notes 57-60 supra and accompanying text.

146. 466 F.2d 316 (D.C. Cir. 1972).

147. Id. at 324-25.

148. Id. at 332 . 
was apparently intended to be applied in those cases where a licensee intentionally filed inadequate ascertainment surveys on repeated occasions and waited until petitions to deny had been filed before submitting amendments; the Stone court noted "it would be unreasonable and harmful to the public interest for the FCC to acquiesce in a pattern of this behavior." 149

In Black Broadcasting Coalition, in addition to the Coalition's other charges ${ }^{150}$ it was alleged that the licensee had filed an inadequate ascertainment survey. ${ }^{151}$ After the petition to deny was filed, the licensee submitted an amendment to its license renewal application which reflected a more current ascertainment of community problems. The Commission accepted the amendment, stating that although Stone had attributed "bad faith" to individual licensees who persist in waiting for a petition to deny before remedying their ascertainment surveys, the petitioners had failed to allege such "bad faith" by the licensee. ${ }^{152}$

On appeal, the circuit court found that the petitioners had properly raised a "bad faith" objection and remanded the case for a determination of this issue. ${ }^{153}$ In so doing, the court implicitly broadened the scope of the "bad faith" exception beyond its limits in Stone. Repeated incidents in which the licensee amended its ascertainment after a petition to deny was filed were not required to be shown. According to the Black Broadcasting Coalition court, the bad faith referred to in Stone could consist of bad faith in conducting the initial survey. If the licensee consciously performed a poor ascertainment survey, hoping that it would go unnoticed if the renewal application was not challenged, the licensee could be considered guilty of bad faith. ${ }^{154}$

As a result of the Black Broadcasting Coalition definition of "bad faith," the adequacy of the original ascertainment is always relevant. If the original ascertainment survey was reasonably adequate, the amendment would not be in bad faith. On the other hand, a poor initial effort at ascertainment of community needs would appear to raise an inference that the amendment was solely for the purpose of responding to the petition to deny. Consequently, the possibility that a licensee can avoid a hearing on the quality of its ascertainment by filing an amendment is extremely slight. If the original ascertainment survey was sufficiently poor to warrant a

149. Id. (emphasis added).

150. See notes 133-42 supra and accompanying text.

151. See Roy H. Park Broadcasting of Va., Inc., 54 F.C.C.2d 995 (1975).

152. Id. at 997.

153. Black Broadcasting Coalition, 556 F.2d at 61 n.2.

154. The Black Broadcasting Coalition court even suggested that a mediocre initial ascertainment that is barely in compliance with the Commission's rules could indicate there was bad faith and reflect adversely on the licensee's character qualifications. Id. 
hearing, this will not be corrected by the filing of an amendment which will be seen to be in bad faith.

\section{Bilingual I and II-Availability of Discovery Before a Hearing is Designated.}

The FCC has promulgated a full set of discovery rules modeled after the Federal Rules of Civil Procedure for use in its adjudicative proceedings. ${ }^{155}$ The Commission's discovery procedure provides for depositions of witnesses in response to oral ${ }^{156}$ or written interrogatories, ${ }^{157}$ service of interrogatories upon other parties, ${ }^{158}$ motions to produce records and physical evidence, ${ }^{159}$ and requests for admissions of facts and genuineness of documents. ${ }^{160}$ Objections ${ }^{161}$ may be made to depositions or interrogatories that are harassing, abusive or outside the permissible scope of discovery. ${ }^{162}$ This discovery machinery is not available to parties until a hearing has been designated. ${ }^{163}$ Therefore, petitioners to deny seeking to have a hearing designated have been unable to use discovery to acquire the information necessary to draft their petitions.

The Communications Act requires petitioners-to-deny to present "specific allegations of fact" sufficient to show that renewal would be "prima facie inconsistent" with the public interest. ${ }^{164}$ The petition must also create a "substantial and material question" of fact as to whether renewing the license would be proper. ${ }^{165}$ If these requirements are not met, the petition is denied without a hearing. ${ }^{166}$ Without pre-designation discovery, petitioners have had no means available to compel licensees to disclose information before a hearing is designated.

In Bilingual Bicultural Coalition of Mass Media, Inc. v. FCC (Bilingual I), ${ }^{167}$ the District of Columbia Circuit recognized the dilemma faced by petitioners to deny, particularly those grounding their petitions on employ-

155. Amendment of Part I of the Rules of Practice and Procedure to Provide for Discovery Procedures, 11 F.C.C.2d 185, 186 (1968).

156. 47 C.F.R. $\S 1.315$ (1976).

157. Id. $\$ 1.316$.

158. Id. $\$ 1.323$.

159. Id. \& 1.325 .

160. Id. $\$ 1.246$.

161. Id. $\S \S 1.319,1.323(\mathrm{~b})$. Once a hearing officer rules on such an objection there is no provision for interlocutory appeal. 11 F.C.C.2d at 190.

162. The scope of discovery is defined as "any matter, not privileged, which is relevant to the hearing issues . . . [or] reasonably calculated to lead to the history of admissible evidence." 47 C.F.R. § 1.311 (b) (1976).

163. Id. $\$ 1.311(\mathrm{a}) ; 11$ F.C.C. $2 \mathrm{~d}$ at 187.

164. 47 U.S.C. $\& 309$ (d)(1) (1970).

165. Id. $\S 309(\mathrm{~d})(2)$.

166. Id.

167. 492 F.2d 656 (D.C. Cir. 1974). 
ment discrimination. In that case, the Bilingual Bicultural Coalition had filed a petition to deny against San Antonio, Texas, station WOAI-TV ${ }^{168}$ charging discrimination in the hiring of Mexican-Americans. ${ }^{169}$ The FCC found the licensee's employment statistics to be within the zone of reasonableness, denied the petition and renewed the license. ${ }^{170}$ Although the District of Columbia Circuit affirmed the FCC's decision, ${ }^{171}$ it did so reluctantly. Finding that the licensee's employment statistics were within the zone of reasonableness, the court commented on the difficult standard that the petitioners were required to satisfy: "The Commission is aware that statistics alone do not provide ideal evidence of discrimination. From Stone to the present case, it has insisted that groups challenging license renewals show 'specific instances of discrimination or a conscious policy of exclusion.' This insistence is understandable, but unrealistic." 172 The court noted that "[d]iscrimination may be a subtle process which leaves little evidence in its wake" and expressed concern that challenging groups had few resources and no procedural tools with which to gather information regarding the reasons underlying statistical disparities. ${ }^{173}$

The court in Bilingual I concluded that the "Commission must consider how best to provide a fair and reasonable opportunity for those challenging license renewals to seek explanations" for statistical disparities, ${ }^{174}$ even in cases where the statistical disparities were within the zone of reasonableness and thus did not necessitate a hearing. ${ }^{175}$ Two possible means to accomplish this goal were suggested: (1) the Commission could provide petitioners with the opportunity to take depositions before deciding whether a hearing is necessary or (2) the Commission itself could scrutinize the licensee's employment practices when the petitioners allege a statistical disparity. ${ }^{176}$

When the court next considered the matter in Bilingual Bicultural

168. Avco Broadcasting Corp., 39 F.C.C.2d 4 (1972).

169. The petition alleged that while San Antonio had a 48 percent Mexican-American population WOAI's staff was only 12 percent Mexican-American. Id. at 8.

170. Id. at 9.

171. 492 F.2d at 660 . The court did not remand the case for further proceedings in light of the opinion because Avco's license was to be considered for renewal again in a few months. The court reasoned that the petitioners would then have the opportunity to avail themselves of any new procedures the Commission had developed. Id. at 659.

172. Id.

173. Id.

174. Id.

175. See notes $65-86$ supra and accompanying text.

176. 492 F.2d at 659 . The court noted that if neither of the alternatives was adopted and "if minorities are not given some means for developing the reasons for statistical disparities, hearings may have to be required based on such disparities alone." Id. (emphasis in original). It is possible that if the FCC does not respond with pre-designation discovery rules, the appellate court's reaction would be to require hearings on statistical disparities alone. 
Coalition of Mass Media, Inc. v. FCC (Bilingual M), ${ }^{177}$ it held that petitioners to deny in certain cases are entitled to pre-designation discovery. Two petitions were considered. In one, the Bilingual Bicultural Coalition challenged the license renewal of another San Antonio station, KONO. ${ }^{178}$ The Coalition relied solely on the disparity between the percentage of minority group members on the licensee's staff and the percentage of minorities in the area work force. ${ }^{179}$ The Commission found the licensee's employment data to be outside the zone of reasonableness ${ }^{180}$ and its affirmative action plan to be inadequate in some respects. ${ }^{181}$ Yet rather than designate a hearing the Commission granted the licensee a conditional renewal. ${ }^{182}$ In the second petition considered on appeal, the Chinese for Affirmative Action (CAA) had challenged the license renewal of San Francisco station KCBS, alleging underemployment of Asians. ${ }^{183}$ As a result of these allegations the Commission requested additional information from KCBS. The station responded with information showing that several Asian employees had not been reported on earlier forms filed with the Commission. ${ }^{184}$ Based on this explanation and the licensee's current efforts in hiring and promotions, the FCC found the licensee's minority employment to be within the zone of reasonableness and its affirmative action plan to be adequate, and granted renewal. ${ }^{185}$ Both the Coalition and CAA had request-

177. No. 75-1855, (D.C. Cir. Apr. 20, 1977), 13 Empl. Prac. Dec. (CCH) I 11,622, vacated on rehearing en banc, No. $75-1855$ (D.C. Cir. May 4, 1978). As this Note went to press, the D.C. Circuit vacated Bilingual II and mandated discovery in cases of substantial statistical disparities only if the FCC is unwilling to conduct further investigation.

178. Mission Central Co., 54 F.C.C.2d 581 (1975).

179. KONO's staff was 18 percent Mexican-American, while the area work force was 44.2 percent Mexican-American. 54 F.C.C.2d at 584-85.

180. The Commission found KONO's employment figures to be unreasonable even though similar figures had previously been held within the "zone." The court noted that the "zone of reasonableness is a dynamic concept" and that it tends to contract over time. 54 F.C.C. $2 \mathrm{~d}$ at 586.

181. Id. at 587.

182. The Commission attached monitoring conditions to the license renewal rather than designate a hearing. $I d$. at 587. Upon a motion for partial reconsideration of the first order by the licensee, the Commission stated that it had considered designating a hearing but chose the monitoring conditions because of the licensee's history of minority employment. Mission Central Co., 56 F.C.C.2d 782, 786 (1975).

183. CBS, Inc., 56 F.C.C.2d 296 (1975).

184. Six Asians hired during the 1971-1974 period did not appear on the record that KCBS filed with the FCC because they had not worked at KCBS for the full designated payroll period. Another was listed as a Spanish-surnamed American. Two others were not listed because their paychecks had been processed manually. They were union employees subject to special provisions that the computerized payroll system was at that time unable to process. Bilingual II, slip op. at 15 n.39, 13 Empl. Prac. Dec. (CCH) I 11,622, at 7326 (Wilkey, J., concurring in part, dissenting in part). A slightly different account is given in the FCC report, see 56 F.C.C.2d at 302 .

185. 56 F.C.C.2d at 302. It appears the Commission used post-license-term data for this "zone" determination. If so the Commission's decision might not be in accord with Black Broadcasting Coalition. See notes 133-42 supra and accompanying text. 
ed discovery before the FCC made its decision to grant renewal. Discovery was denied, ${ }^{186}$ and both cases were appealed on the discovery issue.

In holding that the petitioners should have been given an opportunity for discovery, the District of Columbia Circuit noted that "[r]esponsible opponents making allegations that would constitute a prima facie showing of employment discrimination must be given an opportunity to flesh out the underlying facts, and to inquire into the appropriateness and effectiveness of alternative sanctions." 187 This prima facie showing may be made by (1) statistics indicating a substantial disparity between the licensee's minority employment and the minority representation in the work force or (2) allegations of more particularized discrimination. ${ }^{188}$ The court reasoned that if either of these factors was present and unexplained, the Commission could not legitimately find that renewal would be in the public interest as is required by the Communications Act. ${ }^{189}$ Since there was an indication of possible racial discrimination by the licensee and the Commission did not allow the petitioners to conduct discovery, "[t]he Commission lacked essential data to make a reasoned judgment about whether the public interest had been served in the past or about what was required in the future. "190

Under the court's test, allegations that would not necessarily require a hearing even if proved might still entitle the challenging petitioners to discovery. The FCC has never held that section 309(d) requires a hearing whenever there are allegations of substantial disparity in employment statistics or of isolated instances of discrimination. ${ }^{191}$ However, the court did not

186. The Bilingual Bicultural Coalition requested an order granting it the authority to serve the licensee with written interrogatories and to take depositions of station personnel. The purpose of the discovery was to inquire into the station's "affirmative action plan, job turnover, attrition, firings, testing and application procedures, applicants denied jobs and promotions, names of employees, job descriptions and functions, job supervision, and salaries." 54 F.C.C. $2 \mathrm{~d}$ at 587 . The petitioners also sought permission to file a supplemental petition to deny based on the discovery findings. The Commission denied the request for discovery stating that the information the petitioner requested could be acquired through the monitoring procedures stipulated as part of the licensee's renewal. Id. at 588. See note 182 supra and accompanying text.

Similarly, CAA's discovery request for an order to require KCBS to answer a questionnaire was denied. 56 F.C.C.2d at 303. The Commission said that "nowhere is it alleged that materials required to be furnished to the public by licensees were not furnished . . . and it is no abuse of licensee discretion to insist-as did KCBS-that detailed programming information is too burdensome to compile." Id.

187. Bilingual II, slip op., at 6-7, 13 Empl. Prac. Dec. (CCH) $\llbracket 11,622$, at 7321 .

188. Id. , slip op. at 7, $13 \mathrm{Empl}$. Prac. Dec. (CCH) I 11,622, at 7321 .

189. 47 U.S.C. $\$ 307,309$ (a) \& (e) (1970). It must be remembered that to necessitate a prehearing discovery order by the FCC the discrimination must be inconsistent with the public interest within the context of the Communications Act. Id. $\$ 307$. The FCC has no general public interest power. See NAACP v. FPC, 425 U.S. 662, 670 n.7 (1976).

190. Bilingual II, slip op. at 5, 13 Empl. Prac. Dec. (CCH) ๆ 11,622, at 7321 .

191. We do not contend that this agency has a sweeping mandate to further the "national Policy" against discrimination, nor have we sought to duplicate the detailed regulatory efforts of specialized agencies such as the EEOC. Instead, we have sought 
base its decision on section 309(d) of the Communications Act by which renewal hearings are governed. ${ }^{192}$ Rather, the court focused on the statute's provision that requires license renewals to be in the public interest. ${ }^{193}$ The court indicated that this standard precludes the FCC from renewing licenses without further investigation whenever there is a prima facie showing of employment discrimination. ${ }^{194}$

Judge Wilkey, concurring in part and dissenting in part, eschewed the breadth of the majority's approach. ${ }^{195} \mathrm{He}$ would permit discovery only in cases where the petition to deny contains allegations which, according to Commission precedent, constitute substantial and material questions of fact as to whether renewal is in the public interest, and thus constitute a basis for a hearing. ${ }^{196}$ To satisfy this standard, the petitioner would have to allege that the licensee's employment statistics were outside the zone of reasonableness or that it engaged in a pattern of deliberate discrimination. ${ }^{197}$

to limit our role to that of assuring on an overall basis that stations are engaging in employment practices which are compatible with their responsibilities in the field of public service programming .... Thus, our rules are addressed to the whole public and not to providing individual members of the public with remedies as a result of some discriminatory conduct.

Non-discrimination in the Employment Policies and Practices of Broadcast Licensees, 60 F.C.C.2d 226, 229-30 (1976). See also New York Times Broadcasting Serv., Inc., 63 F.C.C.2d 695, 702-03 (1977).

192. 47 U.S.C. $\S 309$ (d) (1970).

193. Id. $\S 307$.

194. Not only did the Bilingual II court base its decision on the FCC's public interest power and not on section 309(d), but the court characterized the FCC's public interest power as being quite broad. Previously, the FCC's public interest power had been defined to extend to employment practices only "to the extent those practices affect the obligation of the licensee to provide programming that 'fairly reflects the tastes and the viewpoints of minority groups, and to the extent those practices raise questions about the character qualifications of the licensee." N.O.W., 555 F.2d at 1017 (quoting NAACP v. FPC, 425 U.S. 662, 670 n.7 (1976) (emphasis in original)). Even though all acts of discrimination might not fall within this definition, Bilingual II appears to hold that the FCC's public interest power reaches all such acts.

195. Bilingual II, slip op. at 2, 13 Empl. Prac. Dec. (CCH) I 11,622, at 7322.

196. Id., slip op. at 12-14, 13 Empl. Prac. Dec. (CCH) 1 11,622, at 7322.

197. See notes $65-86$ supra and accompanying text. Judge Wilkey concurred in the reversal of Mission Central because the FCC had determined that there was a substantial and material question of fact as to whether the license renewal would be in the public interest. The FCC, by finding that KONO's employment statistics were outside the zone of reasonableness and that its EEO plan was passive, had determined that there were substantial and material issues as to whether renewal of KONO's license would be in the public interest. See notes 178-82 supra and accompanying text. Even so, Judge Wilkey would still be reluctant to allow discovery into past employment practices because of the Commission's "prospective" policy toward employment discrimination. Bilingual II, slip op. at 11, 13 Empl. Prac. Dec. (CCH) 1 11,622, at 7325 (Wilkey, J., concurring in part, dissenting in part). However, in Mission Central the FCC had stated that its choice of remedy turned in part on the licensee's past record. The FCC had brought the licensee's past record into issue, stating it was relevant to its choice of sanctions. Id. See note 182 supra. Therefore an examination of the past employment history was needed for an informed FCC decision as to which sanction to use. Since the FCC did not supplement the record with its own inquiry it was obliged to allow discovery. 
The narrower standard suggested by Judge Wilkey would appear to result in pre-hearing discovery of a more manageable scope than that proposed by the majority. ${ }^{198}$ Under the majority's holding, discovery would be available if a single act of discrimination were alleged, and the scope of discovery would include any such act. Petitioners to deny would be able to investigate statistical disparities in the licensee's employment record even if they were within the zone of reasonableness. Isolated allegations of discrimination could also form the basis for discovery despite the fact that the FCC has held that such allegations even if proved do not warrant a hearing or denial of a license. ${ }^{199}$ Such discovery could not be used to support the allegations in the petition but only to gather evidence for new allegations or as a tool of leverage in bargaining with the licensee. Discovery of this breadth would be subject to abuse. Under Judge Wilkey's formulation, the scope of discovery would be limited to issues that could raise a substantial and material question of fact under section 309(d), as defined by Commission precedents. Such a standard would ensure that petitioners obtaining discovery were using this tool to prepare petitions that meet the section 309(d) test and warrant a hearing.

According to Judge Wilkey the FCC's function under its EEO rules is not to adjudicate whether at any point in the past the licensee was in violation of anti-discrimination laws, but to determine whether the licensee is presently and will continue to be in compliance with the Commission's rules. ${ }^{200}$ This position is clearly correct. Moreover, the majority of the court may be forcing the FCC to play the role of EEO policeman. The Commission may no longer ignore past sins in the face of reform and good intentions. Expansion of the types of discrimination that necessitate a hearing or investigation through discovery, together with the recent restrictions on the use of post-license-term data ${ }^{201}$ suggests that the FCC's EEO role will become more punitive and that its discretion to use the lesser sanctions of short-term renewals and monitoring requirements ${ }^{202}$ will be more limited.

Judge Wilkey dissented in the reversal of $C B S$, Inc. because the Commission had determined that KCBS's statistics were within a zone of reasonableness after receiving a satisfactory explanation of those statistics from KCBS. Id.

198. Judge Wilkey's majority opinion for the court en banc, vacating the Bilingual II panel decision, reflects his concern about the broad scope of discovery envisioned by the panel. Bilingual II, No. 75-1855 (D.C. Cir. May 4, 1978).

199. See notes 65-86 supra and accompanying text. Cf. Amendment of Part I of the Rules of Practice and Procedure to Provide for Discovery Procedures, 11 F.C.C.2d 185, 187 (1968). The FCC decided not to allow the use of discovery to ascertain whether grounds exist for enlargement of issues because such discovery "would be difficult to limit and would offer substantial opportunity for abuse." Id.

200. Bilingual II, slip op. at 11, 13 Empl. Prac. Dec. (CCH) I 11,622, at 7325.

201. Black Broadcasting Coalition, 556 F.2d at 61; see notes 134-42 supra and accompanying text.

202. Bilingual II, slip op. at 3-4, 13 Empl. Prac. Dec. (CCH) I 11,622, at 7323 (Wilkey, J., concurring in part, dissenting in part). 


\section{CONCLUSION}

As a result of the recent changes in the Commission's EEO role, minority groups should have greater success with the use of petitions to deny in the future. Because of Black Broadcasting Coalition's limitations on the use of post-license-term data in evaluating employment policies, licensees will have to run on their license-term record; post-license-term improvement and affirmative action plans will provide no shield. Where there are specific allegations of discrimination during a period when the licensee's performance was outside the zone of reasonableness, a hearing will be mandatory ${ }^{203}$ despite the subsequent improvement.

Even in cases where license-term statistics are within the zone of reasonableness and there is no evidence of a pattern of deliberate discrimination, petitioners may be free to challenge the effectiveness of the licensee's EEO plan. Black Broadcasting Coalition confirmed that the licensee's affirmative action obligations are independent of its duty not to discriminate and suggested that a hearing may be designated to scrutinize a passive EEO plan even when a licensee's statistical disparity is within a zone of reasonableness and there is no active discrimination. ${ }^{204}$

In cases where the licensee's employement statistics are within the zone of reasonableness and it has implemented an adequate affirmative action plan, petitioners may still be entitled to discovery if they can allege a "substantial" disparity in minority employment or individual instances of discrimination. ${ }^{205}$ This will enable petitioners to obtain more easily the evidence necessary to challenge renewal successfully.

Not only should minority groups have more success with challenges based on the Commission's employment discrimination rules, but challenges based on the licensee's ascertainment of community needs should be more feasible as well. Black Broadcasting Coalition's definition of "bad faith" will preclude upgrading of inadequate ascertainments once a petition to deny has been filed. ${ }^{206}$

Thus, recent case law has given minority groups a more powerful mechanism for obtaining responsive programming from licensees through use of petitions to deny. ${ }^{207} \mathrm{An}$ invigorated enforcement of licensees' equal

203. Black Broadcasting Coalition, 556 F.2d at 62; see notes 134-42 supra and accompanying text.

204. $556 \mathrm{~F} .2 \mathrm{~d}$ at $64 \mathrm{n} .21$; see notes $143-44$ supra and accompanying text.

205. Billingual II, slip op. at 7, 13 Empl. Prac. Dec. (CCH) II 11,622, at 7321; see notes 177 94 supra and accompanying text.

206. Black Broadcasting Coalition, 556 F.2d at 61 n.2; see notes 145-54 supra and accompanying text.

207. It is hoped that this tool will not be abused. See Mission Central Co., 54 F.C.C.2d 581, $582-83$ (1975), in which petitioner presented a list of 43 proposals, including a $\$ 2,500$ scholar- 
employment programs should result in increased utilization of minority group members in management positions. Limitations on the use of amendments to ascertainment surveys should have the effect of compelling licensees more adequately to take account of minority group needs. Whether these advancements will have a measurable effect on the responsiveness of programming to minority groups remains to be seen. ${ }^{208}$

ship, a Mexican-American newsman and other demands in such areas as an advisory committee on employment practices, interns, sensitivity training, programming and economic development. The cost of discovery alone, even if the chance of a hearing is not great, might possibly be enough to persuade the licensee to "cave in" to such demands.

208. As noted above in note 177, the panel discussion in Bilingual II was vacated en banc by the D.C. Circuit as this issue went to press. Bilingual II, No. 75-1855 (D.C. Cir. May 4, 1978). The court held that when there is a substantial disparity in a licensee's employment statistics the FCC, before renewing the license, must either conduct its own investigation or provide the petitioners pre-designation discovery. Id. at 5 .

Even if the FCC does choose to conduct its own investigation in such cases, the petitioners will not be left out of the proceedings because the results of the investigation must be made public and the petitioners must be given an opportunity for rebuttal. Id. at 26. The FCC is in the process of revising form 395 to require more detailed information. Petitions for Rulemaking to Amend FCC Form 395 and Instructions, 66 F.C.C. 955 (1977). A more detailed form 395 should lessen the need for pre-designation discovery or additional FCC investigations, since the information to explain most statistical disparities would be available. 
<smiles>CC</smiles> 